\title{
Rua do Catete: A Flânerie como Prática de Intervenção Urbana
}

\author{
Pâmela Paris Ávila
}

Mestra pelo Programa de Pós-graduação em Arquitetura/UFRJ. Pesquisadora no laboratório LASC-UFRJ.

Contato: pamelap.avila@gmail.com

\section{RESUMO}

O ser humano é um ser que se movimenta com ou sem intenção ou objetivo. Ele perambula ou flana descobrindo e explorando o espaço vivido, se apropriando dele através do caminhar pela fruição e pelo prazer de sentir e vivenciar o espaço. Neste presente artigo, a autora vivencia esse espaço na atual configuração da Rua do Catete, no bairro do mesmo nome no Rio de Janeiro. A combinação de trechos preservados com edifícios construídos em terrenos remanescentes de demolições, junto à persistência de vazios urbanos, mostram uma relação transacionalista que oferece a possibilidade de ampliar a compreensão desse objeto de estudo. O objetivo deste trabalho é analisar a evolução do espaço urbano e também dos indivíduos (flâneurs) que habitam e percebem a cidade. Por meio da imersão em campo pelo método da flânerie, inspirado no conceito criado por Walter Benjamin a partir de textos de Charles Baudelaire, é criada uma cartografia textual como ferramenta interpretativa. Esse método possibilita a percepção do espaço focada nos detalhes que se materializam no tempo, revelando outros "territórios" além daqueles demarcados pela história.

Palavras-chave: Rua do Catete; Flânerie; Flâneur; Intervenção Urbana.

\section{The Flânerie as a Practice of Urban Intervention}

\begin{abstract}
The human being is a being that moves with or without intention or objective. He wanders or wanders discovering and exploring the lived space, appropriating it through walking for the enjoyment and pleasure of feeling and experiencing the space. In this article, the author experiences this space in the current configuration of Catete Street, in the neighborhood of the same name in Rio de Janeiro. A transactional relationship that offers the possibility of broadening the understanding of this object of study. The objective of this work is to analyze the evolution of the urban space and also of the individuals (flâneurs) that inhabit and perceive the city. Through field immersion using the flânerie method, inspired by the concept created by Walter Benjamin from texts by Charles Baudelaire, a textual cartography is created as an interpretive tool. This method enables the perception of space focused on details that materialize in time, revealing other "territories", in addition to those demarcated by history.
\end{abstract}

Keywords: Catete Street; Flânerie; Flâneur; Urban intervention.

Revista online do Departamento de Arquitetura e Urbanismo da 


\section{Introdução}

Este trabalho aborda e problematiza a evolução do espaço urbano e dos indivíduos que habitam a cidade pelo viés fenomenológico. Muitas seriam as formas de abordar o cenário atual e muitos os lugares para desenvolvê-las, mas o Rio de Janeiro e, em especial, a Rua do Catete, objeto de estudo da autora em sua dissertação de mestrado, ${ }^{1}$ foram escolhidos para pensar a relação memória/história pela experiência e narrativa do perambular dos habitantes locais.

Segundo Walter Benjamin (2009), a cidade é a realização do antigo sonho humano do labirinto. A essa realidade se dedica o flâneur, que perambula sem pressa pela cidade, rendendo-se à impressão do momento. Para esse indivíduo, a cidade se torna paisagem, parte-se nos seus pólos dialéticos e o envolve como um aposento.

Em seus ensaios sobre Paris, desenvolvidos na década de 1930 e baseados na poesia de Charles Baudelaire (Paris, 9 de abril de 1821-31 de agosto de 1867), Benjamin recupera na Biblioteca Nacional materiais diversificados, como cartas, textos e poemas, produzidos no século XIX. É importante observar esse empenho de um filósofo da história ao se comportar como historiador para desenvolver um novo método. Por esse meio, ensaiou que a materialidade da vida no passado apareceria em elementos esquecidos ou mal iluminados pela história oficial.

Benjamin toma como partido um poeta, sendo justamente na poesia que encontra personagens que se sentem deslocados na consolidação da modernidade. Com isso, consegue mostrar paralelos, como o do poeta e o esgrimista, aquele que luta para conseguir; o boêmio, que se encontra nas tabernas de Paris para conspirar, se organizar e resistir à modernização capitalista em curso; o trapeiro, que é o que recolhe os resíduos do consumo moderno, e o flâneur, que anda sem pressa observando a cidade ao acaso sem objetivo prático. Esses personagens, que são invisibilizados e apagados pela história oficial, são encontrados na poesia por Benjamin. Para ele a melhor maneira de se conhecer uma cidade era perdendo-se nela e mesmo para se pereder-se nela era necessário certa instrução.

O flâneur Benjaminiano, favorecido pelas passagens parisienses que davam abrigo aos compradores dos grandes magazines, é uma figura que tem acesso ao passado histórico ao mesmo tempo que participa da construção do presente. Ele perambula ou flana descobrindo e explorando o espaço vivido e se apropriando dele. Essa prática, a flânerie, é associada por Benjamin principalmente às ruas de Paris e ao fenômeno da multidão que surgiu na modernidade após a Revolução de 1830.

As ruas são a morada do coletivo. O coletivo é um ser eternamente inquieto, eternamente agitado que vivencia, experimenta, conhece e inventa tantas coisas entre as fachadas dos prédios quanto os indivíduos no abrigo de suas quatro paredes. Para este coletivo, as brilhantes e esmaltadas tabuletas das firmas comerciais são uma decoração de parede tão boa, senão melhor, quanto um quadro a óleo no salão do burguês; muros com o aviso "Proibido colar cartazes” são sua escrivaninha; bancas de jornal, suas bibliotecas; caixas de correio, seus bronzes; bancos de jardim, a mobília de seu quarto de dormir; e o terraço do café é a sacada de onde ele observa seu lar. Ali, na grade, onde os operários do asfalto penduram o paletó, é o vestíbulo; e o corredor que conduz dos pátios para o portão e para o ar livre, esse longo corredor que assusta o burguês é, para eles, o acesso aos aposentos da cidade. (BENJAMIN, 1994, p. 33)

A partir dessas observações concretizadas por Benjamin acerca do flâneur, podemos notar que o individuo retratado se seduz pelos usos que são feitos da cidade e pelo seu aspecto coletivo, permanecendo em seu âmbito individual, numa postura que o aproxima mais de um observador distanciado, o que reforça seu caráter dialético. Esta atitude o difere do artista contemporâneo que, ao deambular pelo espaço, propõe seu território guiado pelas suas devidas relações pessoais que tem com o mesmo, onde leva em consideração aspectos culturais, políticos e sociais através de uma relação subjetiva com o espaço.

A partir do método de análise da flânerie, este artigo narra a interpretação do cenário atual da Rua do Catete pela ótica de sua autora. Ao experienciar o local, a pesquisadora dedica uma parte considerável do seu tempo a observar, descrever, anotar e examinar o espaço de estudo. Elementos como usos, percepção espacial e territórios são percebidos e analisados, permitindo a construção de uma cartografia textual, apresentada ao final deste artigo a partir da Rua do Catete como estudo de caso. Essa cartografia enfatiza a importância dos registros do passado para a compreensão dos dias de hoje. São registros permeados de usos cotidianos que se materializam em diversas ações de revisão da história e em diversos cenários da cidade.

Revista online do Departamento de Arquitetura e Urbanismo da Pontifícia Universidade Católica do Rio de Janeiro - PUC-Rio, Brasil Ano 8 - NNo 9 - ISSN 2446-7340 


\section{O ato de perambular: oflâneur de Benjamin e Baudelaire}

$\mathrm{O}$ ato de perambular tem sua origem nos povos nômades; surgiu juntamente com o ato de se deslocar em um espaço para seguir rebanho ou caçar. Antes de qualquer forma de arquitetura, esses atos originaram percursos que deixaram as primeiras marcas humanas na terra. Essas marcas deram início a um procedimento de apropriação e de mapeamento do território e a construção do lugar simbólico em que se desenvolve a vida em comunidade.

Francesco Careri (2013) evidencia essa relação pessoa/ ambiente ao observar que o caminhar implica em uma transformação do lugar e de seus significados. Isso acontece por meio da presença física do homem em um espaço que não foi mapeado, o que configura uma forma de transformação da paisagem, modificando o significado do espaço culturalmente e, consequentemente, fazendo dele um lugar.

Demarcado historicamente pela figura urbana doflâneur, o ato de perambular pela cidade nasce a partir de um típico indivíduo parisiense que se torna um personagem comum na paisagem da cidade. Benjamin (2009) declara que "a cidade é o autêntico solo sagrado da flânerie". O filósofo recorre à flânerie como metodologia para seus estudos por meio da observação, leitura e criação de textos a fim de decodificar os significantes urbanos. Para o filósofo, a cidade pisca para o flâneur, que se aproveita do ato, e para ela, produz prosas e versos, como os vistos nos escritos de Baudelaire.

Benjamin identifica o flâneur como personagem típico das obras de Baudelaire ao perceber a relevância desse indivíduo em seus textos, mas seu interesse está principalmente na relação entre a vida e a obra de Baudelaire. A figura do flâneur lhe permite articular a ideia de choque em relação às mudanças sociais, à reestruturação das analogias temporais e espaciais e, principalmente, a reorganização espaço-temporal da experiência, como apresentado na obra do poeta.

Sozinho ou em grupo, o flâneur é uma personalidade ociosa que é estabelecida a partir da modernidade e busca vivenciar na cidade a experiência originária do nômade. Para o flâneur, os caminhos são diversos e as possibilidades inúmeras, não somente no sentido poético e figurativo, mas porque o texto filosófico, como o idealiza Benjamin, é uma obra aberta. Talvez isso leve a que a imagem do flâneur na própria personalidade de Baudelaire lhe con- fira aquela plasticidade que você sente falta [...]. Para tanto, desenvolverei a problemática do "tipo" num sentido eminentemente filosófico [...]. (BENJAMIN e SCHOLEM, 2003, p. 340)

A flânerie, enquanto atividade de contestação entusiasmou outros movimentos estéticos, como o movimento dadaísta e a metodologia da deriva.

Guy Debord (1956) ressalta que a primeira ação dadaísta foi precisamente na cidade de Paris, onde vagueava o flâneur. Com o Dadaísmo, a flânerie se apresenta como um movimento de operação estética em que o passeio descrito por Benjamin nos anos vinte é visto como forma de arte e se inscreve inteiramente no espaço e no tempo.

O interesse pelas vivências nas cidades gera também o método da deriva. Essa, por sua vez, é uma atividade lúdica e coletiva que busca a experimentação de novos comportamentos na vida real por meio da realização de modos alternativos de habitar a cidade que, como o dadaísmo e a flânerie, se situam fora e contra as regras da sociedade burguesa.

O conceito de deriva está ligado indissoluvelmente ao reconhecimento de efeitos da natureza psicogeográfica, e à afirmação de um comportamento lúdicoconstrutivo, o que se opõe em todos os aspectos às noções clássicas de viagem e passeio. [...] As lições da deriva permitem estabelecer os primeiros levantamentos das articulações psicogeográficas de uma cidade moderna. (DEBORD,1956, tradução nossa, p. 02)

A deriva é uma metodologia móvel que surge com o manifesto situacionista de Debord, que aborda a ideia da rua como lugar do imponderável e se ajusta aos constantes movimentos e fluxos de pessoas e ideias que ocorrem no ambiente urbano. Entre os diversos procedimentos situacionistas, a deriva se apresenta como uma técnica de passagem rápida por ambientes variados e, enquanto método resgata a atividade da flânerie para analisar e entender os significantes da vida urbana.

\section{Caminhar como intervenção urbana: a construção de uma cartografia textual}

Careri (2013) defende que o caminhar é uma forma de intervenção urbana, embora a prática tenha sido esquecida pela maioria dos arquitetos e seja realizada com mais frequência por filósofos e poetas. O autor vê o percurso como um espaço

Revista online do Departamento de Arquitetura e Urbanismo da 
anterior ao espaço arquitetônico, um espaço imaterial e simbólico que durante milhares de anos representou um meio estético através do qual era possível habitar o mundo.

O percurso transformou-se em um gênero literário ligado à descrição e representação do espaço. Um exemplo é o conceito de "cidade texto" de Benjamin (1987). É um método de escrita cuja principal personagem é a grande cidade moderna e seu movimento de destruição do antigo e de construção dos novos tempos - que também virão a ser destruídos no futuro. A percepção da metrópole como espaço textual nos permite a sua leitura e de diversas tensões modernas. Benjamin se coloca perante a metrópole de modo análogo ao estudioso em frente à escritura, de modo que o ambiente urbano se transforma em texto. Assim, se constitui um retrato complexo dos conflitos que dominam a metrópole, a ser lida.

É mérito da interpretação benjaminiana ter mostrado como os temas cidade e modernidade são ao mesmo tempo determinantes e inseparáveis. Em Rua de Mão Única (BENJAMIN, 1987), a cidade se configura como um microcosmo de uma cidade-texto. Nela, a ausência de linearidade e de coerência visível se torna uma forma de crítica e determina um entrelaçamento entre forma e conteúdo. A minuciosa leitura dos "resíduos" da cidade pressupõe um mistério cifrado que se expressa na concretude dos objetos urbanos.

Ao caminhar, o indivíduo está "nu diante do mundo [e, ] ao contrário dos motoristas e usuários de transportes públicos, o caminhante se sente responsável por suas ações, está à altura do ser humano e dificilmente pode esquecer a sua humanidade mais elementar", como analisa David Le Breton (2011, p. 18). Para Michel de Certeau (1994), ao caminhar, os participantes ordinários da cidade criam a cidade que percorrem. Constroem, assim, uma maneira de apropriação do espaço ao perambular e vivenciar as paisagens, transformando a errância em um ato de intervenção urbana.

O simples ato de andar pelo lugar se torna estratégia para igualmente interagir com elementos da população com os quais cruzamos nas ruas. Moradores, frequentadores, ou simples passantes, todos motivam oflâneur a perfilar personagens, descrever ações e estilos de vida a partir de suas atuações cotidianas. E todos são bons momentos para se retraçar os cenários onde transcorrem suas histórias de vida e, sendo assim, delinear os ambientes dos inúmeros ramos de significados que abrigam os territórios de uma cidade.

Segundo George Perec (1975), condenamos, há muito, o nosso ato de ver a cidade ao puro condicionamento mercadológico e espetacular. Vemos o mundo com olhos objetivos e mecanizados e procuramos decodificar apenas o funcional e o utilitário. François Laplatine (2013), por sua vez, aborda a etnografia como um modo de estudo feito através do caminhar que não é apenas uma atividade de observação, mas também uma atividade linguística que vai do que se vê na paisagem para a escrita. Descrever, escrever e construir fazem acontecer o que não se compreendia.

Segundo John Jackson (1984), as ruas já não conduzem apenas a lugares, elas mesmas são lugares. Sendo espaço de encontro, o caminhar se revela útil à arquitetura como instrumento cognitivo e projetual, como um meio de reconhecimento do indivíduo em meio ao caos do espaço urbano e como forma de inventar novas modalidades de intervenção nos espaços públicos que os torne visíveis.

A pesquisadora então assume o papel do flâneur e estabelece a sua presença no local como de uma voyeur urbana, uma contempladora e narradora da cidade, que narra a realidade que nos escapa, lançando-se no vazio e dando valor ao ordinário. A narrativa apresentada neste momento tenta explicar, descrever e espacializar o tempo na Rua do Catete através da construção de uma cartografia textual.

A intenção é mostrar como podemos ter o olhar do acontecimento na cidade, descobrir a interação espaço/indivíduo e como as diferenças fundam territórios, recriando e ressignificando cada espaço através do caminhar, a partir do qual as pessoas não apenas se introduzem no espaço urbano, mas principalmente negociam seu próprio lugar no mundo.

Sendo assim, através da construção dessa cartografia textual, a autora buscou o entendimento dos espaços por meio de suas percepções sensíveis durante suas vivências do percurso, consolidando assim o campo para sua pesquisa.

\section{Rua do Catete, um passeio pelo tempo}

A história da Rua Catete remonta ao início do século XVIII, quando a região era ocupada por chácaras e olarias. Foi nessa época que o trecho passou a ser chamado Estrada do Catete. O cronista Luís Gonçalves dos Santos (1767-1844), mais conhecido como Padre Perereca, não usou nem meia página ao descrevê-la para Dom João VI.

A estrada do Catete é larga, e por um e outro lado poucas casas tem à frente dela, sendo quase toda bordada de cercas das chácaras, que ocupam o terreno, por onde passa a dita estrada, mas sobre os outeiros até a praia de

Revista online do Departamento de Arquitetura e Urbanismo da Pontifícia Universidade Católica do Rio de Janeiro - PUC-Rio, Brasil Ano 8 - NNo 9 - ISSN 2446-7340 
Botafogo, inclusivemente se veem muitas e boas casas de campo. (GERSON, 2013, p. 293)

Já no início do segundo reinado, a rua é transformada, ficando estreita, curva e tomada por residências de alto valor aquisitivo, onde buscaram habitar fidalgos e abastados comerciantes. A mais famosa delas foi a do desembargador Manuel Jesus de Valdetaro. Donos de muitas terras, os Valdetaros possuíam uma em especial, que se transformaria após alguns anos em palácio presidencial. Porém, antes disso, entre 1856 e 1867, abrigou a residência urbana do Barão de Nova Friburgo, projetada pelo arquiteto alemão Gustav Waehneldt e situada na esquina das ruas do Catete e Silveira Martins. Através da leitura de Brasil Gerson (2013) descobre-se por que o arquiteto não colocou o palácio no meio do parque e sim na estranha posição em que se encontra, nas esquinas das Ruas do Catete e Silveira Martins.

Relembrava há pouco Teófilo de Andrade que foi por causa da Baronesa, no dia em que pela primeira vez viu seus alicerces sendo lançados: - Ó, Barão, pensas que vou descer lá da Fazenda, no meio do mato, para viver aqui cercada de mato também? Quero a casa dando de janelas para a rua! (GERSON, 2013, p. 293)

Durante o período republicano, segundo Gerson (2013), o Catete (ver Figura 1) foi rapidamente se aburguesando, no sentido que tem a palavra burguesa de coisa vulgar e corriqueira. Já não era mais o bairro aristocrático e sim de gente média e casas de móveis, condição essa que veio a se misturar com outra aposta, de bairro de estudantes, na sua maioria boêmia, de escritores e jornalistas propensos à boêmia.

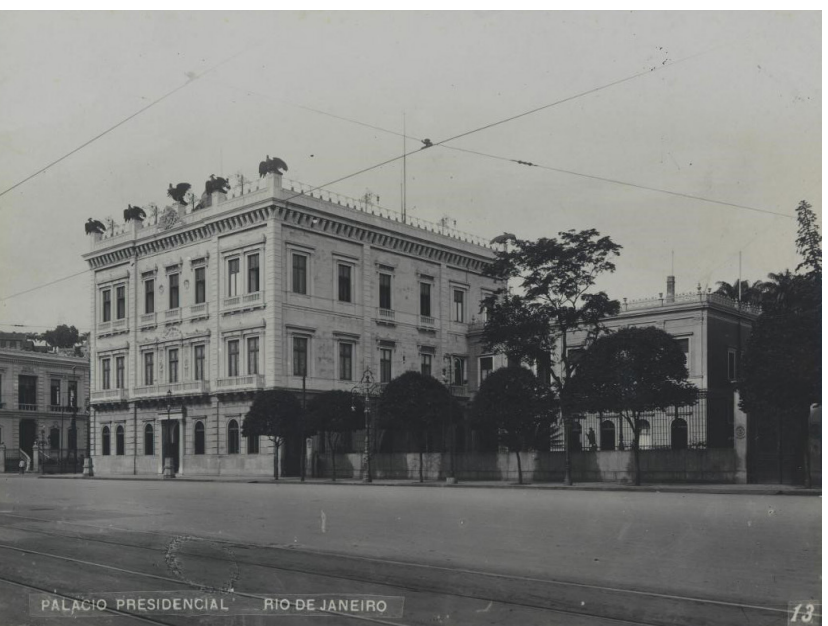

Figura 1. Palácio do Catete, Rio de Janeiro, RJ, 1914.
No ano de 1897 , a sede da República se instala no edifício que passa a ser conhecido por Palácio do Catete e todo o seu entorno sofre mudanças de ambiente e identidade. Políticos começaram a se instalar em hotéis e residências no bairro. Aqueles que já desfrutavam de prestígio, como o Hotel dos Estrangeiros, localizado na Rua Barão do Flamengo, onde atualmente se encontra o Condomínio do Edifício Simon Bolívar, tornaram-se sede de articulações políticas famosas.

O Rio de Janeiro, Capital da República de 1897 a 1960, reuniu no bairro do Catete o centro das decisões do país, o que, por conseguinte, colocava seu entorno como um dos mais atrativos do país à época. Sua ocupação ocorreu de modo gradativo, reunindo diversas tipologias de edificação e de influências estilísticas. Posteriormente, com a transferência da capital para Brasília, o bairro sofreu marcado esvaziamento.

O Catete testemunhou diversos momentos (passagem do metrô, saída da sede da República e algumas implementações de planos urbanos) que configuraram a trama urbana e cultural do Rio de Janeiro. Como apontam Paulo Mendonça, Marina Nascimento e Danilo Bueno (2013), viu o aparecimento da Belle Époque, construiu sobrados imponentes, condescendeu aos modernistas e aos traços geométricos do Art Déco, assistiu à revolução política e social da década de 3o, à ditadura de Vargas e ao início da real industrialização do Brasil. Passou por toda a era desenvolvimentista do período Juscelino Kubitschek que introduziu no país as fábricas automotivas e realizou a construção de Brasília, mudando para a cidade o centro de decisões do país.

Isso leva a uma percepção da história desgarrada da experiência do presente e que não permite perceber o quanto estas áreas urbanas se constituíram como espaços idealizados da cidade. Nesses termos é que se pode dizer que os bairros históricos se constituem como lugares de memória. (MENDONÇA; NASCIMENTO; BUENO, 2013, p. 14)

O bairro do Catete foi um dos bairros que sofreu uma grande transformação em razão de mudanças e interdições que obras trouxeram para o ambiente. $O$ tecido urbano que se encontrava consolidado desde o meio do século XX, após passar por mudanças desde a gestão do prefeito Pereira Passos, esvaeceu-se. Entre as principais mudanças, figura a demolição de grande parte dos sobrados que, durante o Brasil Colônia e o Império, foram residências das elites, grandes referências do bairro e da cidade, como a garagem dos bondes, o Cinema São Luiz e o Café Lamas, que faziam parte do casa-

Revista online do Departamento de Arquitetura e Urbanismo da Pontifícia Universidade Católica do Rio de Janeiro - PUC-Rio, Brasil Ano 8 - NNo 9 - ISSN 2446-7340 
rio do lado ímpar da rua. Todas essas edificações e também a Escola Rodrigues Alves, vizinha do Palácio do Catete, foram colocadas abaixo pelas obras do metrô.

A demolição de grande parte do casario de numeração ímpar da Rua do Catete destruiu o cenário bucólico, embora sombrio, daquela rua. O largo que se abria no espaço fronteiro ao Palácio do Catete, após um percurso estreito em curvas, era de uma dramaticidade inigualável. Hoje, uma ampla perspectiva se abre de longe, acabando com aquele fator que a urbanista portuguesa Maria da Luz chama de espaço da surpresa. (SECRETARIA DE PATRIMÔNIO CULTURAL, [2005?], p. 5)

O bairro ficou totalmente sitiado durante as obras do metrô, os moradores viviam entre as ruínas dos velhos prédios que antes abrigavam as mais tradicionais lojas de móveis da cidade, bares boêmios e cinemas tradicionais. Entre os bares e esquinas que restaram de pé, a rua enfrentava problemas que duraram alguns anos, como o lixo que se acumulava, a falta de luz e de gás, o telefone que falhava e o imenso barulho. Apreensivos, os comerciantes aguardavam em suas lojas vazias o tão esperado dia da reurbanização. O quarteirão que menos sofreu com demolições de edifícios foi o que vai da Rua Correa Dutra até a Rua Silveira Martins, em frente ao Pa-

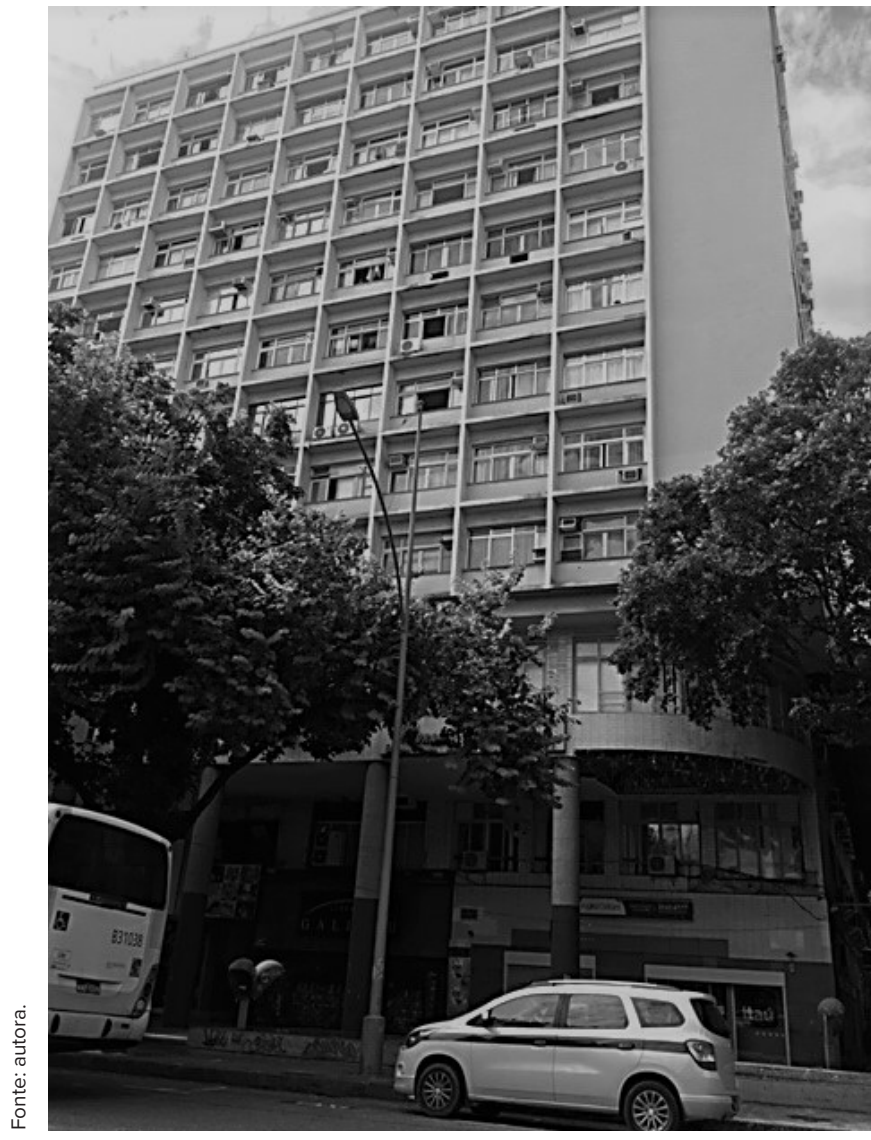

Figura 2. O edifício Rua do Catete no 347 , que seguiu o modelo do plano agache, localizado na esquina com a Rua Almirante Tamandaré.

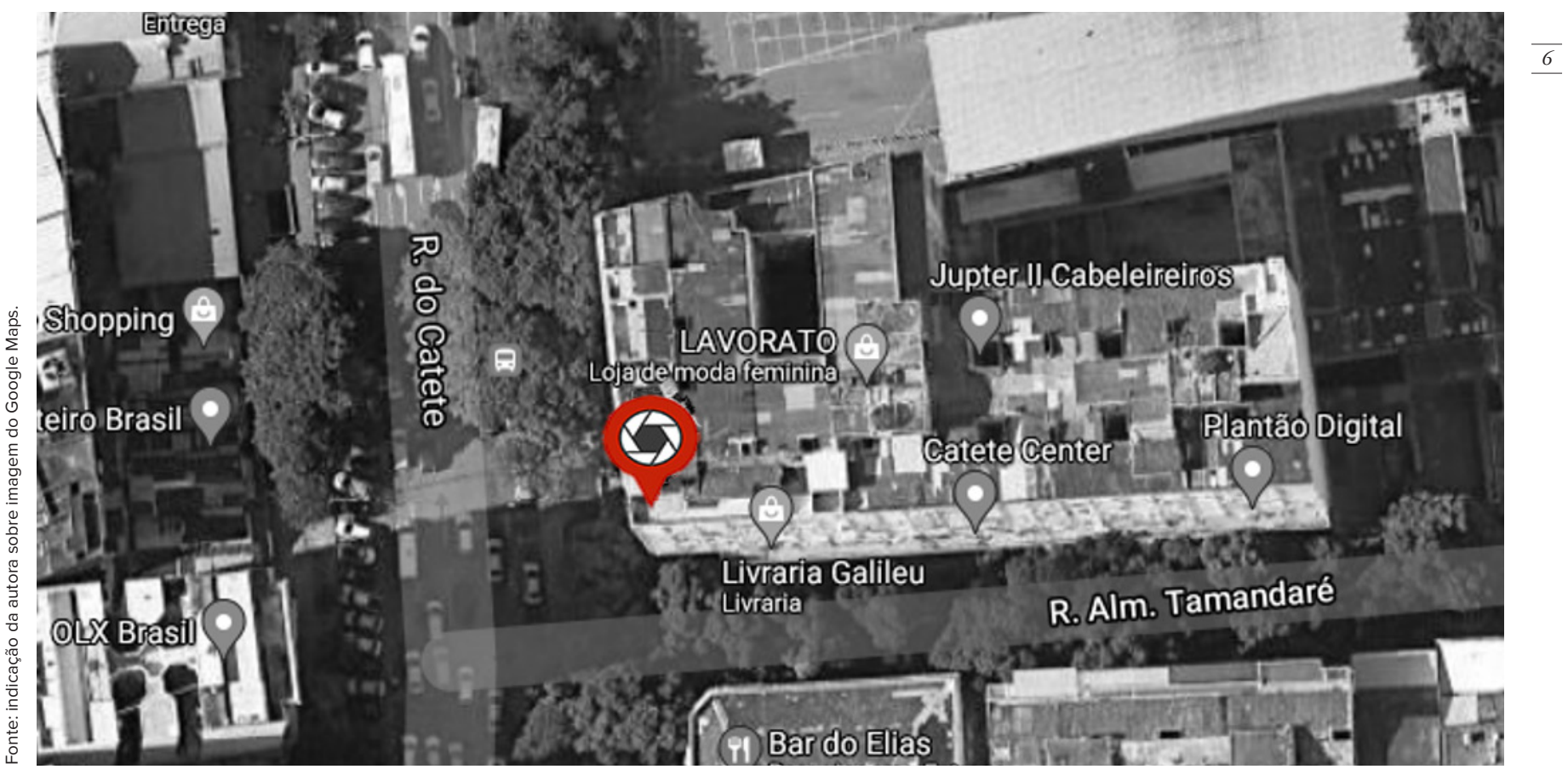

Figura 3. Localização do edifício Rua do Catete no 347, que seguiu o modelo do Plano Agache, localizado na esquina com a Rua Almirante Tamandaré.

Revista online do Departamento de Arquitetura e Urbanismo da

Pontifícia Universidade Católica do Rio de Janeiro - PUC-Rio, Brasil

Ano 8 - No 9 - ISSN 2446-7340 
lácio do Catete, pois os imóveis são tombados pelo Instituto do Patrimônio Histórico e Artístico Nacional.

Um novo projeto de urbanização do Catete previa a reformulação completa da área. Todas as casas, palacetes, prédios e sobrados seriam demolidos para que no local fossem construídos edifícios baseados no Plano Agache. ${ }^{2}$ Apenas um edifício, na esquina da Rua Almirante Tamandaré, foi construído seguindo o modelo do Plano - o restante do projeto não chegou a sair do papel (Figuras 2 e 3).

O Projeto de reurbanização do Catete provocou uma tática de renovação fundamentada na intervenção no espaço público em que o processo de elaboração exige trabalhar a fragmentação da cidade. Existe, entretanto, uma fragmentação negativa, que é a exclusão, e uma fragmentação positiva, que permite a multiplicidade de identidades, sendo essa esta última a que se buscou trabalhar no Catete no ano de 1996 durante a execução do projeto Rio Cidade.

Com projeto de Jorge Mario Jáuregui, ${ }^{3}$ a intervenção do projeto Rio Cidade (1996) na Rua do Catete consistiu na reformulação do eixo viário/comercial/histórico que conecta o centro da cidade com os bairros da zona sul. O resultado foi dado por transformações urbanísticas desde a modificação do traçado e dos níveis das ruas até a criação de praças. As transformações infraestruturais demandaram obras importantes de drenagem (embora a Rua do Catete ainda hoje alague em alguns trechos em dias de fortes chuvas), novo mobiliário urbano e plantio de renovação das áreas de jardins. O projeto buscou planejar uma conexão entre o "lugar histórico" e o "lugar presente", em que o histórico registrado nos monumentos e nos sobrados recebeu tratamento de materiais, equipamentos e iluminação diferenciados do resto, e o atual ficou registrado na sequência de singularidades do bairro.

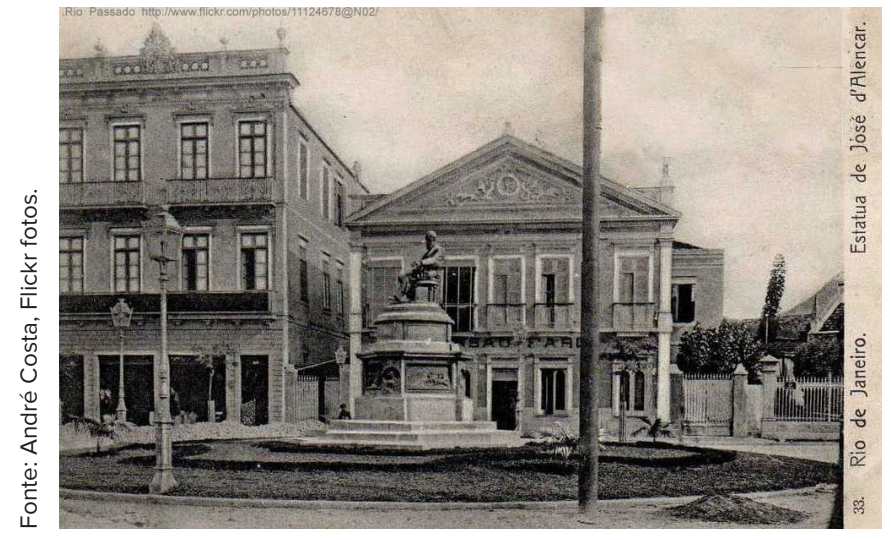

Figura 4. Praça José de Alencar, 1906.
A Praça José de Alencar foi reformulada e uma nova estátua do escritor, semelhante à que existia no local no início do século, sentado em uma cadeira, foi posicionada no centro de uma rótula. A rótula fica no início da Rua do Catete, dividindo os bairros do Catete, Laranjeiras e Flamengo. Anteriormente à reformulação da praça (Figura 4), o local era perigoso e de difícil trânsito para os pedestres. A reformulação da via impôs limites à circulação dos automóveis favorecendo o transeunte. O traçado das ruas foi modificado, recebendo novo tratamento dos pisos e, ao redor da praça, foram instalados paralelepípedos com a finalidade de reduzir a velocidade da passagem dos automóveis na área.

O Largo do Machado também foi reformulado, tendo sido realizada a restauração do projeto paisagístico de Burle Marx. Ademais, foi previsto o estacionamento subterrâneo (não concretizado) e a elevação do nível da rua que dá continuidade à Rua Gago Coutinho, incorporando-a ao domínio dos pedestres.

Entre as ruas Correa Dutra e Pedro Américo, onde se localiza a área histórica do bairro com os sobrados do século XIX e o Palácio do Catete, foi feito um novo traçado da via e as calçadas receberam pisos de granito semelhantes aos já existentes na calçada do palácio, que foi alargada com o intuito de criar uma praça ${ }^{4}$ que, se concretizada, seria usada como um lugar para extensão das atividades do centro cultural do Museu da República. Apesar das inúmeras mudanças que a Rua do Catete passou após os planos urbanísticos, uma das suas maiores mudanças de identidade não se deu por culpa de nenhum desses planos e sim pelo esvaziamento econômico que ocorreu após a saída da sede da República do Palácio do Catete.

\section{Uma flâneire cateteana}

Neste texto, busquei mostrar minhas impressões que foram recolhidas durante um passeio pela Rua do Catete, entre as ruas Andrade Pertence e Ferreira Viana. Por meio de uma narrativa crítica e um pouco literária, procurei demonstrar minhas impressões em fotos produzidas durante a caminhada e anotações feitas durante o percurso.

Terça Feira, dia 30 de Março de 2021, um dia quente no Rio de Janeiro, sensação térmica acima de 40 graus. Penso na melhor forma de sair de casa nessas circunstâncias. Entro na estação do metrô do Flamengo, compro um bilhete, saio correndo ao escutar o barulho do trem e consigo chegar a tempo de entrar no vagão. O contraste do calor externo com o gelado do ar-condicionado é agradável e penso que,

Revista online do Departamento de Arquitetura e Urbanismo da Pontifícia Universidade Católica do Rio de Janeiro - PUC-Rio, Brasil Ano 8 - No으 9 - ISSN 2446-7340 
infelizmente, são só duas paradas - Flamengo e Largo do Machado - até a Estação Catete.

Sigo em direção às escadas rolantes que levam até a calçada da Rua do Catete, oposta à entrada do Museu da República. Durante a subida, saio do ambiente nebuloso em direção ao clarear que vai aparecendo aos poucos, como saísse de uma caverna em direção à luz que cinematizava o local. Aquele ponto se tornou uma passagem entre dois mundos.

Ao passar pelo portal de luz, aproximo-me à esquina das Ruas do Catete com Silveira Martins. O céu era uma explosão de azul e calor, com poucas nuvens que mais pareciam manchas de suor remanescentes de uma grande aquarela. O comércio popular toma conta do local, pessoas vêm e vão. Apesar de ainda estarmos em período de quarentena, em virtude da COVID-19, a rua está sorteada de passantes que repartem o espaço com os camelôs que fazem parte da paisagem lo-

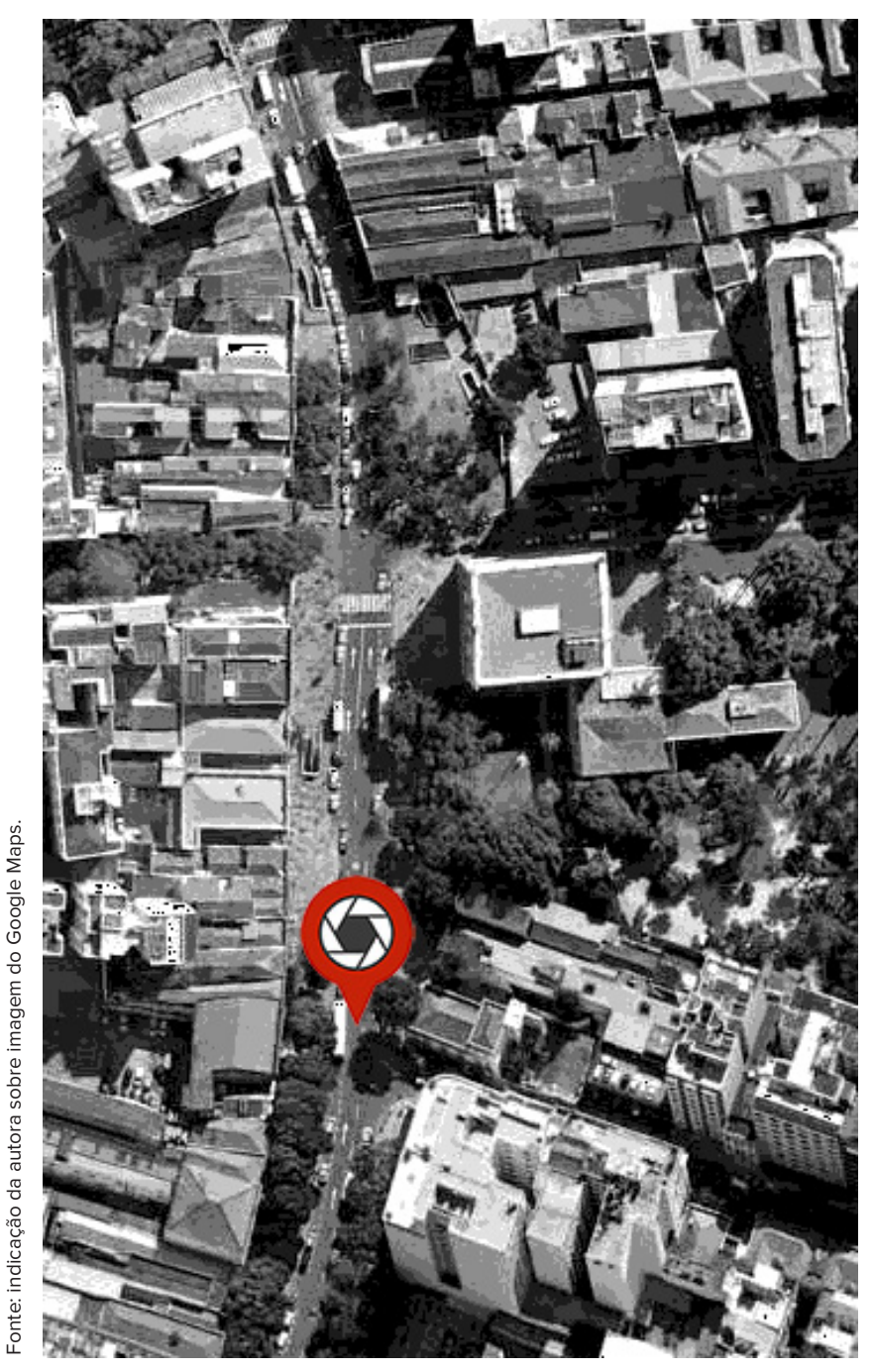

Figura 5. Localização do início da Flânerie.
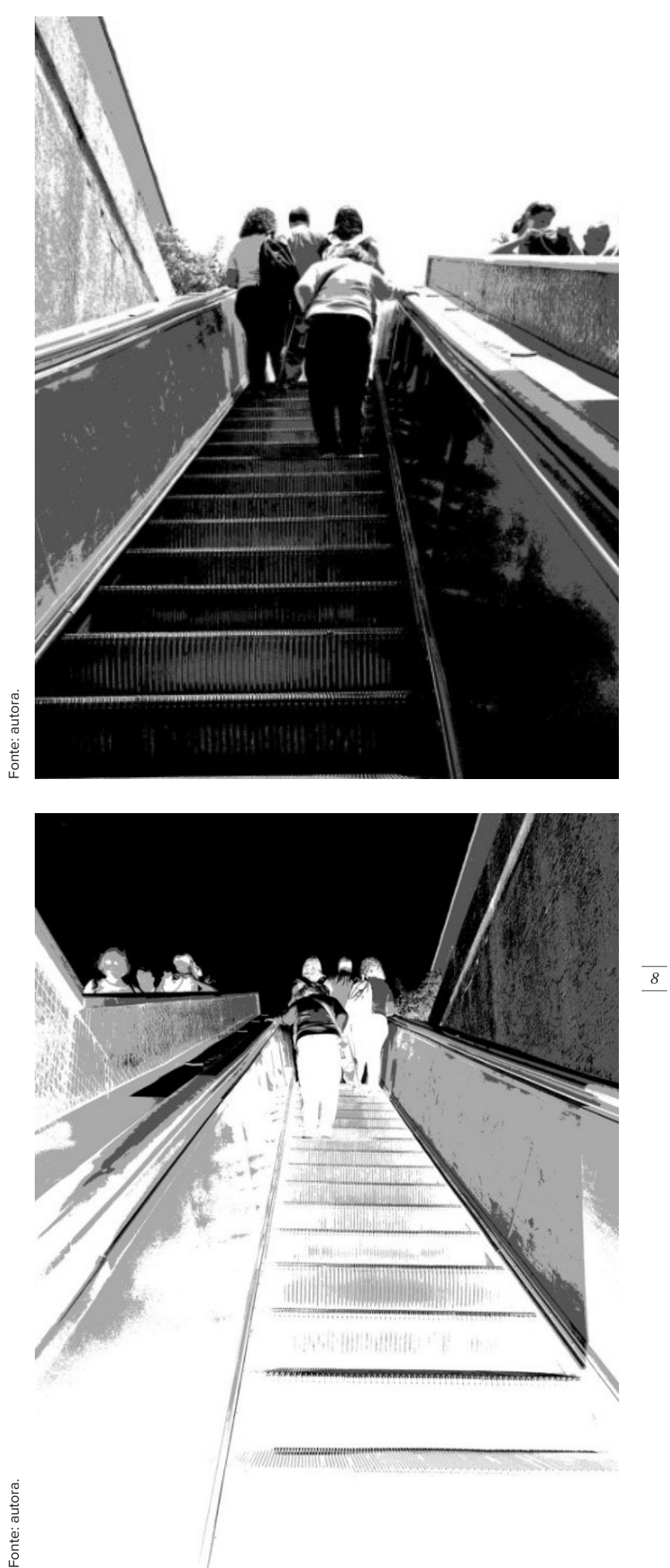

Figura 6 e 7 (de cima para baixo). Saída da Estação Catete.

Revista online do Departamento de Arquitetura e Urbanismo da Pontifícia Universidade Católica do Rio de Janeiro - PUC-Rio, Brasil Ano 8 - No 9 - ISSN 2446-7340 
cal. Atravesso a rua e nesse momento me encontro em frente ao Palácio do Catete. O local está impregnado de memórias, parece que somente as águias de asas abertas instaladas no pináculo do edifício sabem disso. Fico angustiada, pois elas não podem sequer me contar.

Lembro-me de Machado de Assis em Esaú e Jacó, de 1904:

[...] a cobiça de Santos ao olhar para o palácio e relatar as águias, uma cobiça de possuí-lo, sem prever os altos destinos que o palácio viria a ter na República; tão exposta como aqui no Catete, passagem obrigada de toda a gente, que olharia para as grandes janelas, as grandes portas, as grandes águias no alto, de asas abertas. (ASSIS, 2004, p. 36)

Estou nesse momento na calçada do Museu da República, também conhecido como Palácio do Catete. Realmente é uma calçada de memórias, incluindo as "memórias" do me- trô que ali deixou, como marcas, seus enormes respiradores que, a cada vez que o trem passa abaixo, fazem com que a rua pareça ter sido atacada por um dragão adormecido que acabou de acordar. Na esquina com a Rua Ferreira Viana, há dois sobrados imponentes e bem conservados vizinhos ao Museu da República: o Museu do Folclore e o Centro de Convenções. Preciso dizer que essa esquina me causa um grande incômodo, do lado esquerdo fica um belo sobrado, de valor arquitetônico, e no lado direito um prédio enorme espelhado que parece que acabou de "pousar" no terreno. Trata-se do Hotel Florida, que nada tem a ver com espaço e nem com o entorno, e chega a doer os olhos.

Resolvo voltar para frente do palácio do Catete. Logo na sua lateral, à esquerda, podemos notar mais cicatrizes deixadas pela passagem do metrô, onde hoje se abrigam seus respiradores (a casa dos dragões adormecidos). A calçada é extremamente mais larga e ali fica localizada uma das saídas da estação. $\mathrm{O}$

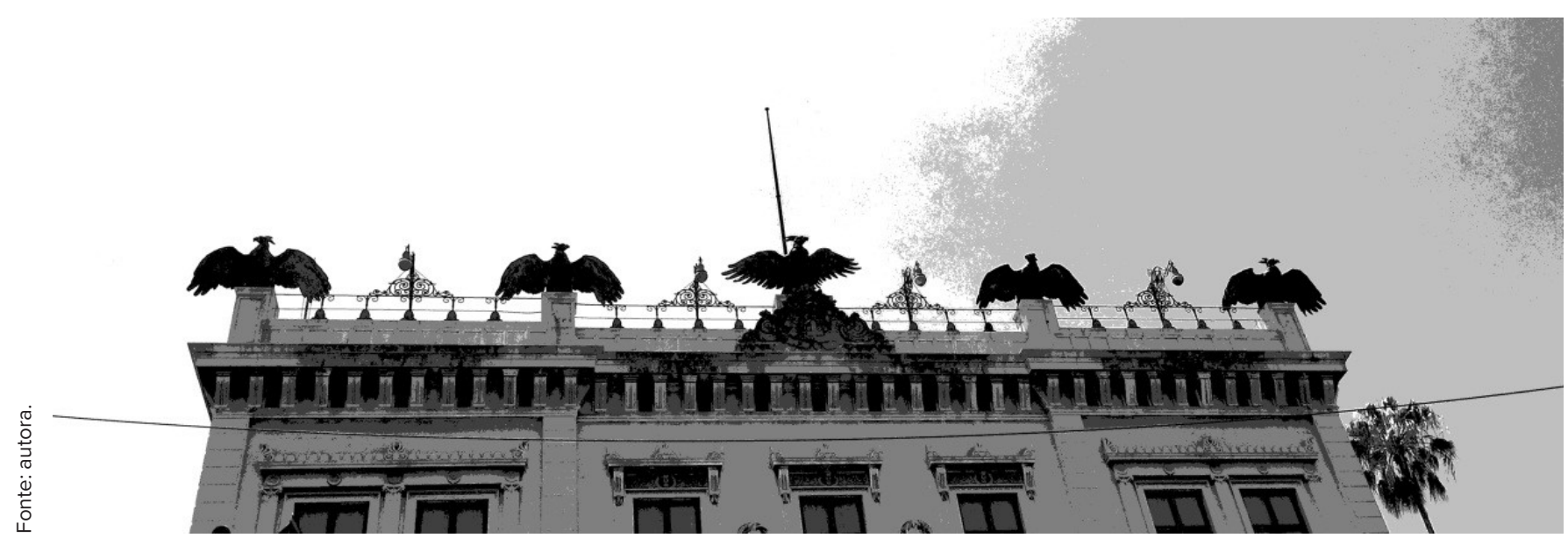

Figura 8. As águias do Palácio do Catete.
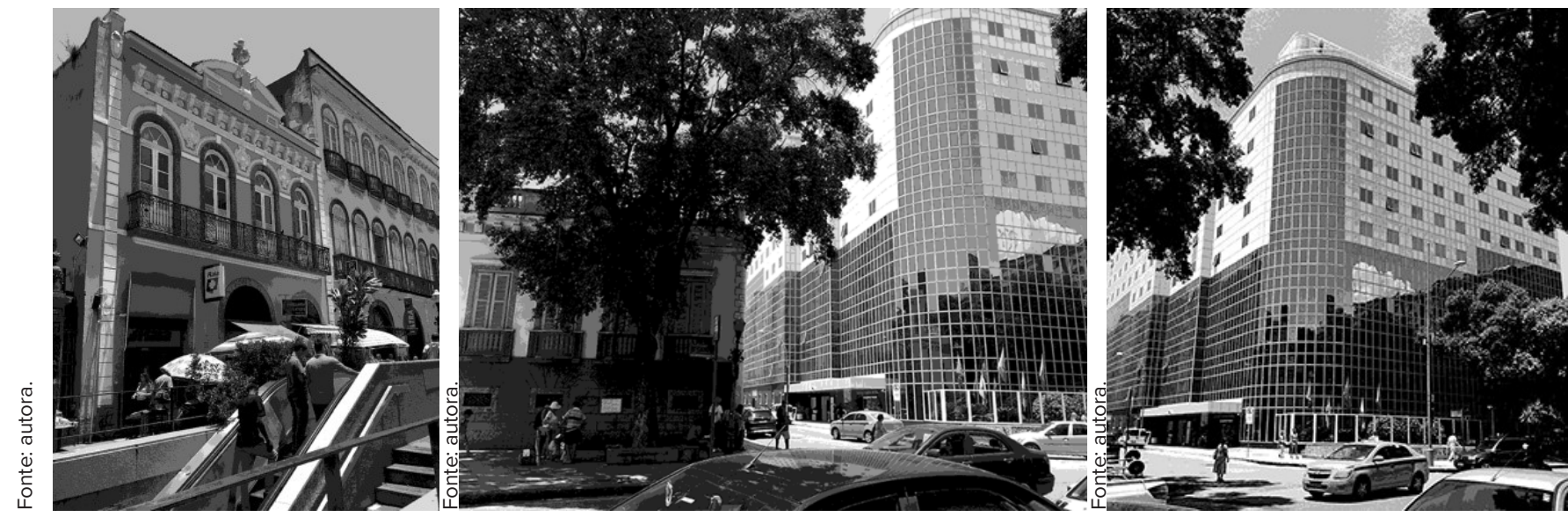

Figuras 9-11 (da esquerda para a direita). Saída da estação Catete do metrô e a discrepância da esquina com a Rua Ferreira Viana.

Revista online do Departamento de Arquitetura e Urbanismo da Pontifícia Universidade Católica do Rio de Janeiro - PUC-Rio, Brasil Ano 8 - No으 9 - ISSN 2446-7340 


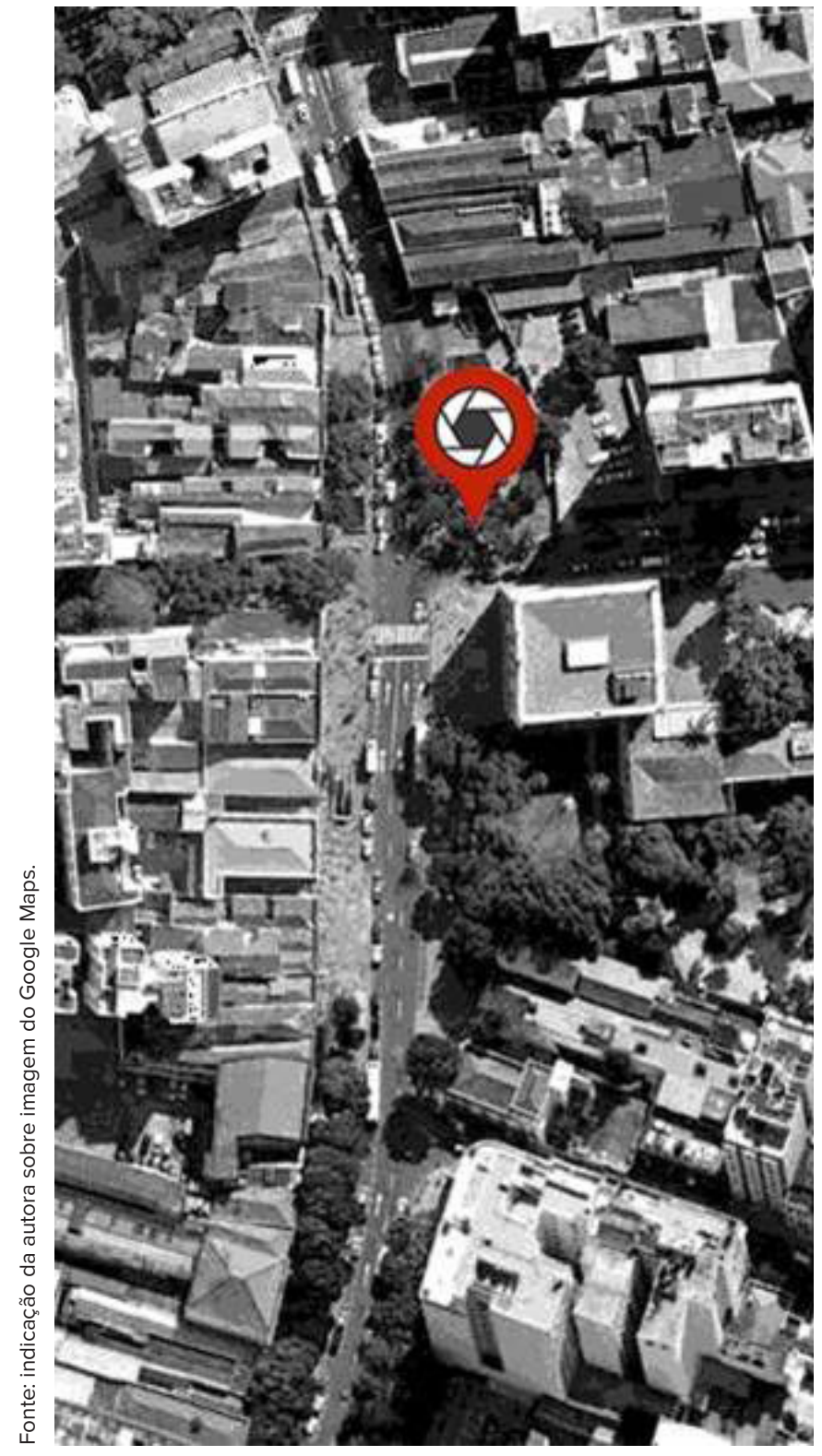

Figura 12. Localização da Flânerie.
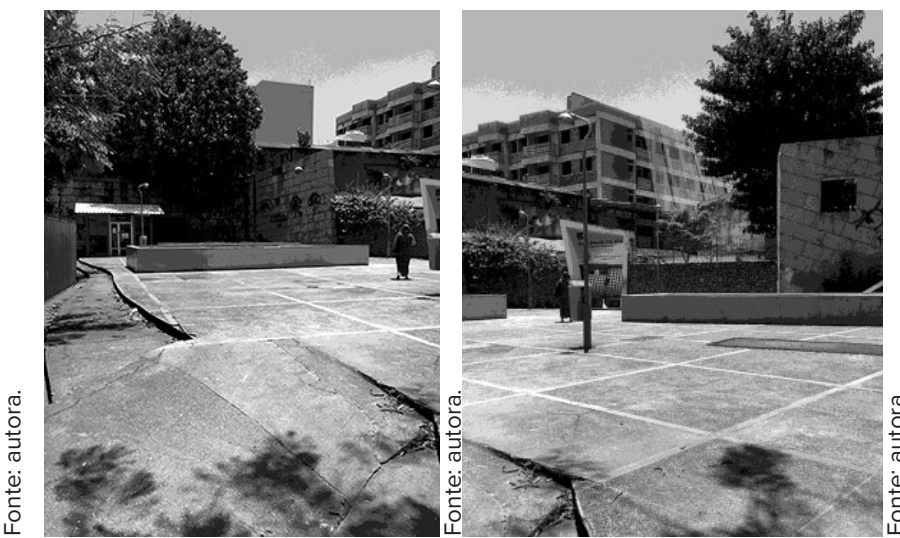

metrô vem valorizando e destruindo, às vezes não sei se o preço pago por essa valorização não foi alto demais.

Não sei se foi acertado derrubar a Escola Rodrigues Alves, vizinha do Palácio do Catete - que possuía uma bela arquitetura, semelhante à da Escola Amaro Cavalcanti, no Largo do Machado -, e chamar o grande vazio que hoje ali se encontra de "praça". Hoje temos no espaço a Praça do Poeta - acredito que não citam o nome para não magoar o certo poeta. O espaço não dispõe de mobiliário urbano para os moradores e está completamente vazio, está mais para praça dos respiradores (do metrô) do que praça do poeta. O local está cercado por grades e, mesmo quando se encontram abertas, não oferece atrativo algum à população do bairro. Com aparência árida, está sempre vazio, ao contrário do seu entorno, de circulação intensa.

Sigo pela mesma calçada da praça do Poeta, na Rua do Catete, em direção à Glória. Passo por sobrados vizinhos à praça $\mathrm{e}$ me deparo com quatro edificações em diferentes estágios: enquanto uma se encontra abandonada, duas estão na eminência de cair. Uma delas parece sobreviver comprimida no meio do abandono e esquecimento, mostrando que nada está perdido e que seus vizinhos ainda têm chance, que não devem desistir.

Olhando do outro lado da calçada, na altura da Rua Andrade Pertence, os sobrados se encontram em melhores condições. Foram tomados pelo comércio e não há nenhum vestígio de moradia: no térreo, o comércio e, em cima, estoque ou abandono. A única lembrança do passado são os detalhes das fachadas que sobrevivem ao tempo.

Voltando em direção à estação do metrô do Catete, posso ver os sobrados que ainda estão em condições de uso. Estão tomados pelo comércio. São lanchonetes, bares, lojas de doces e farmácias.

Figuras 13-16 (da esquerda para a direita). Praça do Poeta, cercada por grades e com seus respiradores do metrô.

Revista online do Departamento de Arquitetura e Urbanismo da

Pontifícia Universidade Católica do Rio de Janeiro - PUC-Rio, Brasil

Ano 8 - NNo 9 - ISSN 2446-7340 


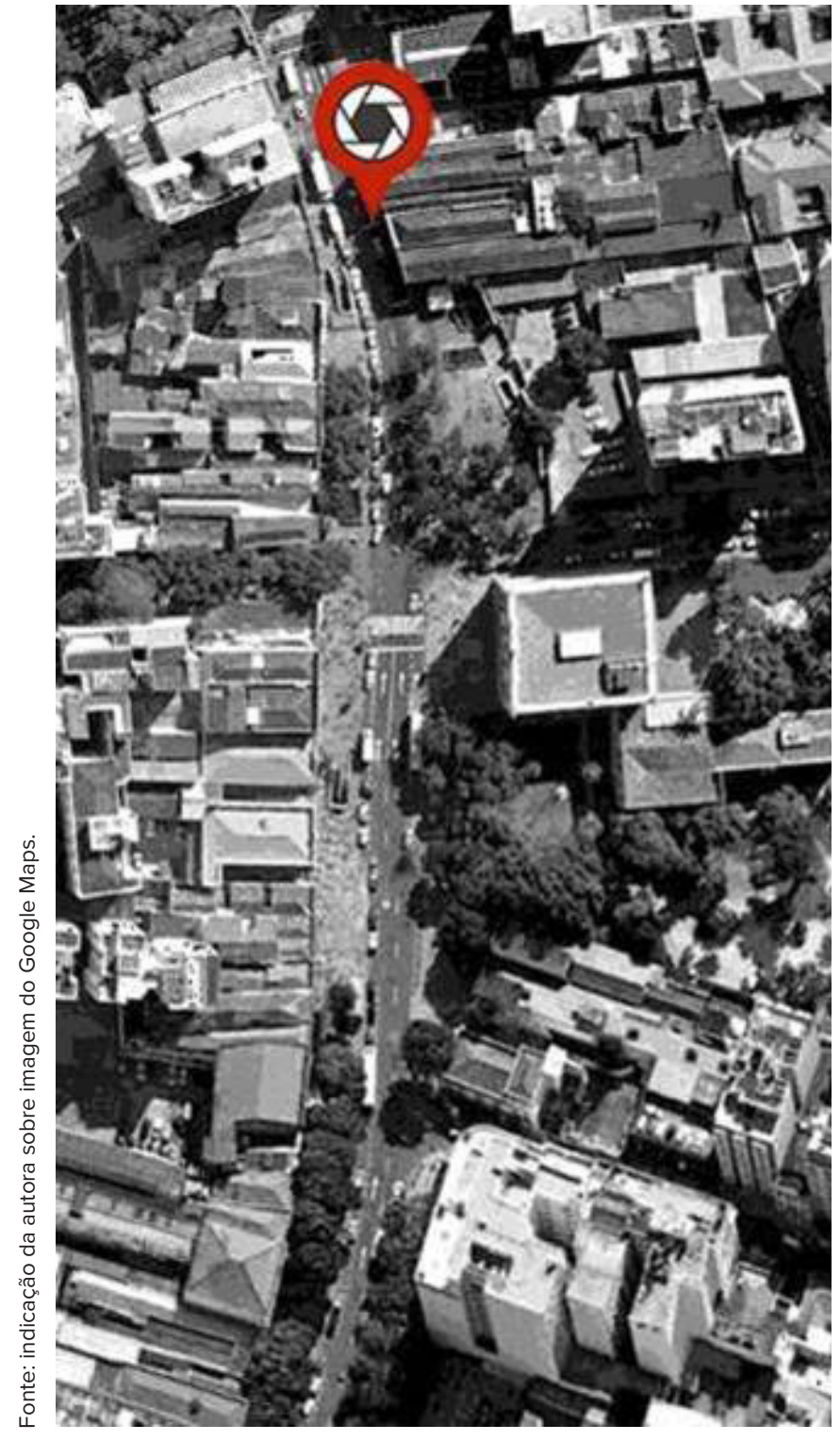

Figura 17. Localização da Flânerie.
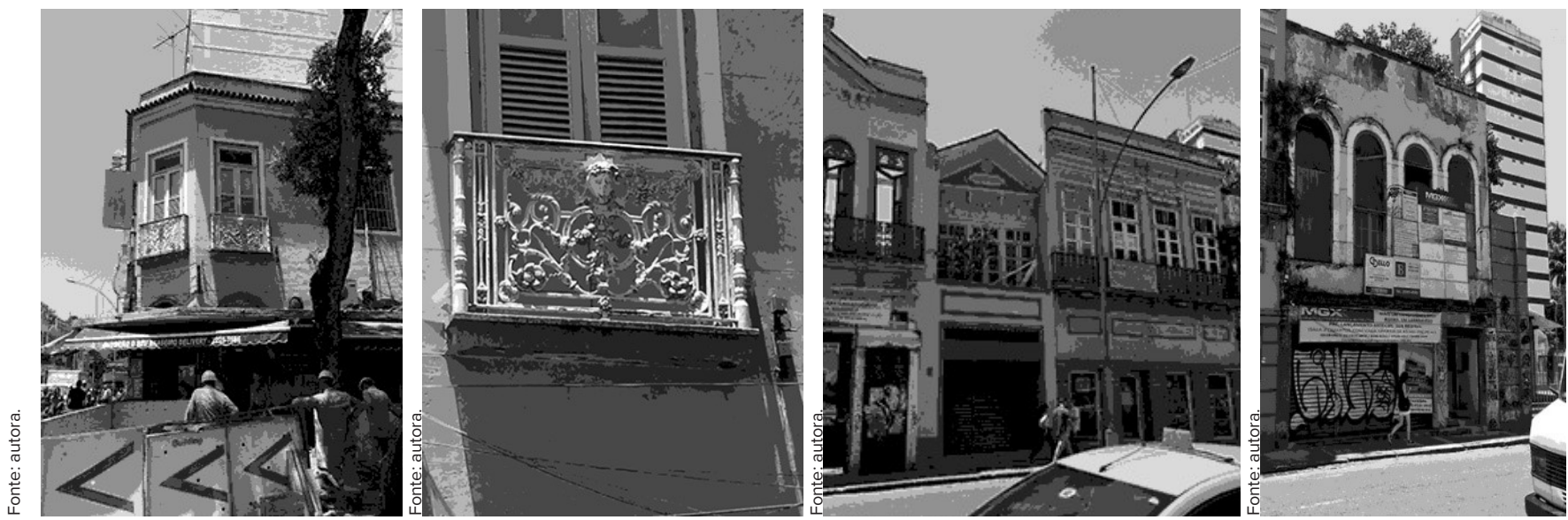

Figura 18-21 (da esquerda para a direita). Sobrados na Rua Do Catete, vizinhos à Praça do Poeta e esquina com a Rua Andrade Pertence.

Revista online do Departamento de Arquitetura e Urbanismo da

Pontifícia Universidade Católica do Rio de Janeiro - PUC-Rio, Brasil

Ano 8 - No 9 - ISSN 2446-7340 


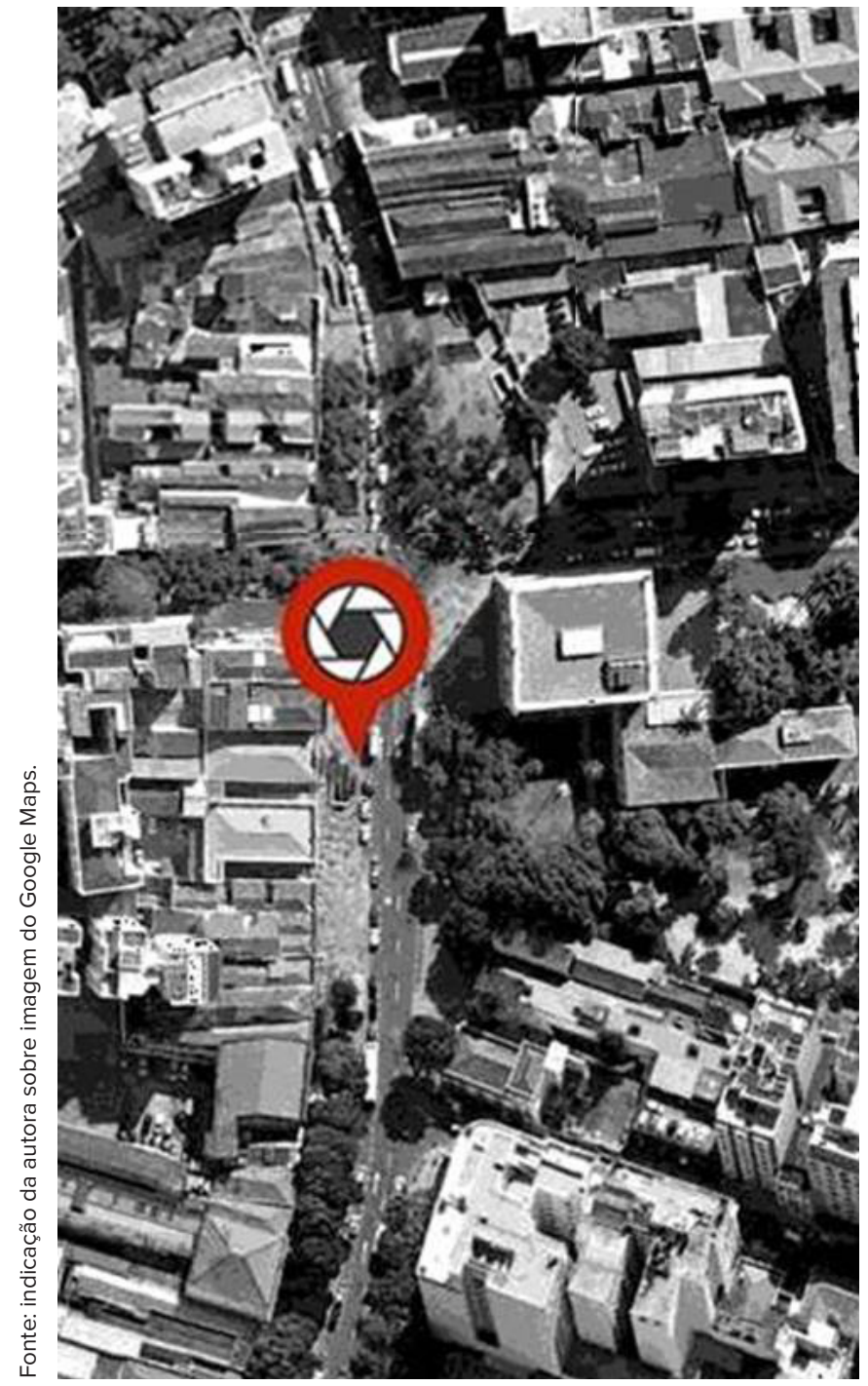

urbano dentro do suposto caos do espaço da cidade, é possível tentar buscar uma relação entre os dois por meio do discurso errático. O que conseguimos descobrir é um complexo sistema de espaço público que pode ser atravessado sem solução de continuidade.

Nos dias de hoje, caminhar significa enfrentar muitos medos, que incluem o medo da cidade, do espaço público e muitas vezes dos outros indivíduos, frequentemente percebidos como inimigos potenciais. O espaço urbano é o reflexo de movimentos transitórios e cotidianos, sendo através da vivência do indivíduo no espaço que acontece a percepção do mundo, em que o ambiente configura a existência. Avaliando que é por meio dessas vivências que negociamos a relação com o espaço, entender como esses procedimentos acontecem e como se constituem é importante para entendermos o nosso próprio espaço e história, pois a cidade é construída pelas vivências dos indivíduos e relações diárias de uso.

Por um lado, a arquitetura, enquanto representação de tempos e grupos culturais, pode descrever uma sociedade por meio dos espaços e seus símbolos e de experiências cognitivas. Por outro, o conjunto de informações armazenadas pela experiência ou aprendizagem é construído ao longo de nossa vida, até mesmo antes de nascermos. Sendo assim, há uma relação próxima entre o espaço que vivenciamos e as informações e emoções que retemos, pois erigimos nossa espacialidade e nosso conhecimento de acordo com o tempo, os acontecimentos e seus cenários.

Figura 22. Localização da Flânerie.

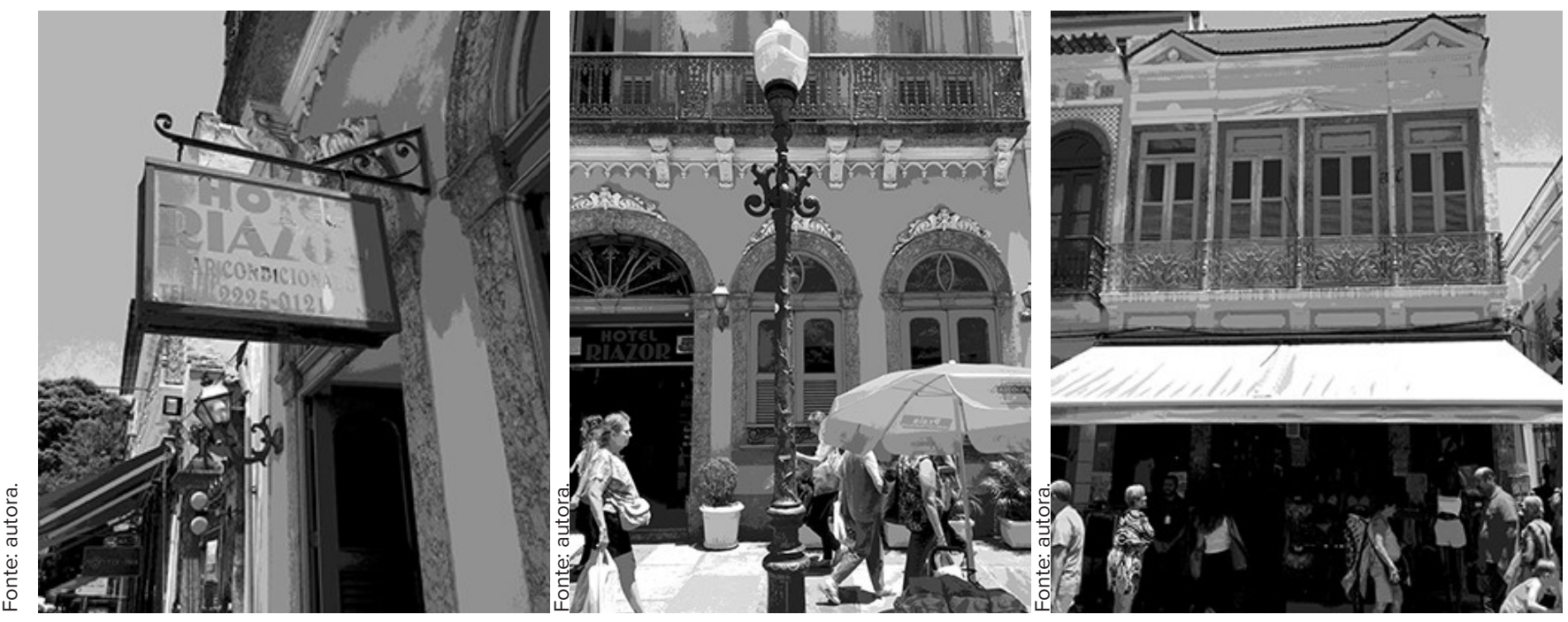

Figura 23-25. Sobrados na Rua Do Catete, calçada oposta ao Palácio do Catete.

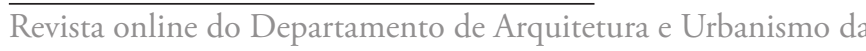
Pontifícia Universidade Católica do Rio de Janeiro - PUC-Rio, Brasil Ano 8 - No 9 - ISSN 2446-7340 


\section{Notas de fim:}

1. ÁVILA, Pamela Paris. Uma outra estória: Representações da rua do catete pelas narrativas do 'palácio de memórias'. 2020. Dissertação (Mestrado em Arquitetura) - Faculdade de Arquitetura e Urbanismo, Universidade Federal do Rio de Janeiro. Rio de Janeiro, 2020.

2. "Na memória dos cariocas, eles [sic] não desfruta do mesmo prestígio de Pereira Passos ou Pedro Ernesto. Mas, justiça seja feita: o paulista Antônio Prado Júnior foi o primeiro governante do Rio a patrocinar um plano-diretor para o então Distrito Federal. Sua gestão, entre 16 de novembro de 1926 e 24 de outubro de 1930, foi marcada pela abertura de ruas, calçamento, mudanças de alinhamento, obras de saneamento e construção de escolas.

Filho de uma família tradicional, nomeado pelo amigo e presidente da República Washington Luís, Prado Júnior, que não tinha curso superior, contratou o urbanista francês Alfred Agache para elaborar o Plano de Remodelação, Extensão e Embelezamento da Cidade. O projeto, que ficaria conhecido como Plano Agache, pretendia organizar o crescimento do Rio, determinando áreas de expansão, prevendo a criação de redes de serviço e tratando da instalação da infraestrutura urbana.

O trabalho do urbanista nunca foi inteiramente aplicado no Rio, embora tenha servido de base para meia dúzia de planos diretores. [...]” (NO FIM DOS ANOS 20, 2013).

3. Jorge Mario Jáuregui é um "carioca" de origem Argentina. Entre seus principais trabalhos, todos na cidade do Rio de Janeiro, estão a Requalificação Urbana da Rua do Catete (programa Rio-Cidade); o Mobiliário Urbano para a zona sul e a Urbanização de mais de vinte favelas em diferentes locais da cidade (Programa Favela-Bairro).

4. Esta praça não foi absorvida pela cidade da maneira planejada, pois elaborada sem mobiliário urbano utilizável pela população, se tornou somente um local de passagem e saída do metrô. Neste mesmo conjunto da reforma, a Rua do Catete ainda possui duas "praças" que não deram certo. Uma delas é o espaço localizado na entrada da Vila Elite, vizinha ao antigo prédio da UNE: o espaço foi revitalizado e pensado em torno de uma grande boca de ventilação do metrô, mas não possui qualquer relação com as atividades locais ou com a escala do corpo humano, estando em estado de abandono.

\section{Referências Bibliográficas:}

ASSIS, Machado. Esaú e Jacó. Rio de Janeiro: Nova Fronteira, 2004.

ÁVILA, Pamela Paris. Uma outra estória: Representações da rua do catete pelas narrativas do 'palácio de memórias'. 2020. Dissertação (Mestrado em Arquitetura) - Faculdade de Arquitetura e Urbanismo, Universidade Federal do Rio de Janeiro, Rio de Janeiro, 2020.

BAUDELAIRE, Charles. Sobre a modernidade (O pintor da vida moderna). São Paulo: Paz e Terra, 2011.

. Pequenos poemas em prosa. 2. ed. São Paulo: Hedra, 2009.

BENJAMIN, Walter. Rua de mão única. São Paulo: Brasiliense, 1987.

. Passagens. Belo Horizonte: Editora UFMG; São Paulo: Imprensa Oficial do Estado de São Paulo, 2009.
O Flâneur. In: BENJAMIN, Walter. Obras escolhidas III. Tradução: João Carlos Martins Barbosa; Hemerson Alves Baptista. São Paulo: Brasiliense, 1994.

; SCHOLEM, Gershon. Correspondência. São Paulo: Perspectiva, 2003

CARERI, Francesco. Walkscapes: o caminhar como prática estética. São Paulo: Gustavo Gili. 2013.

CERTEAU, Michel de. A Invenção do Cotidiano. Petrópolis: Vozes, 1994 .

DEBORD, Guy. Theorie de la derive. Les Lèvers Nues, Bruxelles, n. 9, nov. 1956 .

GERSON, Brasil. Histórias das ruas do Rio. 4. ed. Rio de Janeiro: Brasiliana, 2013.

JACKSON, John Brinckerhoff. Discovering the Vernacular Landscape. New Haven: Yale University Press, 1984.

JACQUES, Paola Berenstein (Org.). Apologia da Deriva: Escritos situacionistas sobre a cidade. Rio de Janeiro: Casa da Palavra, 2003.

IPHAN-RJ. Apac: Catete. 2004. Disponível em: http://wwwo.rio.rj.gov .br/patrimonio/apac/apac_catete.shtm. Acesso em: 26, nov. 2017.

MENDONÇA, Paulo Knauss; NASCIMENTO, Marina B.; BUENO, Danilo André. Arquivos Vivos da Administração Pública: O Programa de Gestão de Documentos do Estado do Rio de Janeiro (PGD-RJ). Cadernos do Desenvolvimento Fluminense, Rio de Janeiro, n. 3, nov. 2013 .

NO FIM DOS ANOS 20, Plano Agache pretendia organizar o crescimento do Rio. Acervo $O$ Globo, Rio de Janeiro, 17, out. 2013 Disponível em: https:/acervo.oglobo.globo.com/rio-de-historias /no-fim-dos-anos-20-plano-agache-pretendia-organizar -crescimento-do-rio-10403129. Acesso: 22, dez. 2021.

LAPLATINE, François. Arquitetura e Antropologia. In: DUARTE, Cristiane Rose; VILLANOVA, Roselyne de (Org.). Novos Olhares sobre o Lugar: ferramentas e metodologias, da Arquitetura à Antropologia. Rio de Janeiro: Mauad, 2013.

LE BRETON, David. Elogio del Caminhar. Madri: Siruela, 2011.

PEREC, Georges. Tentative d'épuisement d'un lieu parisien. Paris: Christian Bourgois, 1975.

PREFEITURA DA CIDADE DO RIO DE JANEIRO. Área de Proteção do Ambiente Cultural. Catete/Glória - APAC - 2005. Disponível em: http://www.rio.rj.gov.br/web/irph/apac. Acesso em: 24, out. 2017.

SECRETARIA DE PATRIMÔNIO CULTURAL da Prefeitura da Cidade do Rio de Janeiro. Área de Proteção do Ambiente Cultural: APAC - Catete. [2005?]. Disponível em: http://wwwo.rio.rj.gov.br/patrimonio /apac/anexos/catete_textos.pdf. Acesso em: 24, out. 2017. 